\title{
EVRITMIJA V DELOVNEM PROCESU Proces jaz-ti-mi kot nova metoda za izobraževanje na delovnem mestu
}

\section{POVZETEK}

$V$ besedilu je predstavljena metoda evritmija za podjetja in organizacije, ki je bila $v$ Sloveniji uporabljena prvič. Izobraževanje poteka med delovnim časom z namenom ustvarjanja in negovanja pogojev za dobre medosebne odnose na delovnem mestu, cilj izobraževanja pa je prebujanje posameznika za podrobnosti, ki se pojavljajo $v$ delovnih procesih in so pomembne za ustvarjanje dobre klime $v$ timu ali celotni organizaciji. Izobraževanje izvedemo s pomočjo evritmije v štirih korakih, poimenovanih: prostor, čas, odnosi, intenca.

Ključne besede: evritmija, timsko delo, podjetje, organizacija, usposabljanje

\section{EURHYTHMY AS PART OF WORK PROCESS - ABSTRACT}

Organizational and enterprise use of Eurhythmy has only recently begun to be incorporated into the work process. The purpose of the training is to create and maintain conditions that foster good relations in a workplace. The goal is to raise awareness of the details of the work processes that contribute to creating a "good vibe" within a team or organization context. Eurhythmy enables us to achieve that through following four methodical steps: space, time, relations and intention.

Keywords: eurhythmy, team work, enterprise, organisation, training

Mag. Primož Kočar, podjetje EVPOS, primoz.kocar@evpos.si 


\section{UVOD}

S pomočjo izbranih evritmijskih vaj smo izvedli prvi pilotni projekt evritmije $\mathrm{v}$ delovnem procesu v Sloveniji. Usposabljanju, ki je potekalo v septembru 2014, je bilo namenjenih 10 delovnih dni, in sicer vsak dan po 20 minut delovnika. V tem času so se udeleženci srečali sami s seboj in med seboj, in sicer drugače kot običajno. Čeprav smo se dnevno družili samo po 20 minut, je bilo iz pogovorov očitno, da so vaje v njih sprožile proces prebujanja za zavedanje različnih detajlov vsakdana.

Med sodelavci v različnih organizacijah lahko v delovnih procesih prihaja do drobnih anomalij, ki vsakodnevno spodjedajo dobre medsebojne odnose in ustvarjalno vzdušje. Če teh procesov ne ozavestimo, lahko vodijo do izčrpanosti, notranje odpovedi in apatije. Vodjem ne preostane drugega, kakor da posegajo po virih, ki obljubljajo vzvode za motiviranje sodelavcev. Nihče pa se ne vpraša, ali ni v trenutku, ko začnemo razmišljati o tem, kako bomo motivirali druge, za vse skupaj že prepozno. Ali lahko sodelavca, ki je notranje že zdavnaj »dal odpoved«, z zunanjimi vzvodi prepričam, da naj »odpoved« raztrga in vrže $\mathrm{v}$ koš ter se $\mathrm{z}$ vso energijo zažene $\mathrm{v}$ delo?

$\mathrm{Z}$ evritmijo za podjetja oziroma evritmijo $v$ delovnem procesu stopamo na novo pot ustvarjanja in negovanja dobrih medosebnih odnosov na delovnem mestu. Izhodišče našega delovanja je teza, da vsak socialni sistem ustvarjajo njegovi akterji. Hkrati pa socialni sistem ustvarja kontekst, v katerem akterji delujejo (Scharmer, 2011). Ta teza nam odpira možnost, da kot posamezniki vplivamo na lastno delovno okolje. Da bi temu izhodišču zaupali, ga moramo doživeto spoznati v življenjski situaciji. Iz takšnega spoznanja se v posameznikih prebudi motivacija za nadaljnje delovanje. Kajti samo če sami neprisiljeno ugledajo smisel lastnega delovanja, so lahko motivirani za delo. Evritmija za podjetja ustvari varen učni prostor, ki ga v dani situaciji tvorijo udeleženci sami. S svojim delovanjem ustvarijo nov socialni sistem. V njem je mogoče izumiti in uvajati novosti. Udeleženci prek vaj doživijo, kako njihova lastna koncentracija in izvrševanje nalog vplivata na delovanje celotne skupine. V sebi najdejo vzvode, ki jih morajo potegniti z namenom, da funkcionira celota. Naučijo se videti, kaj njim in skupini prinaša odgovorno delovanje in da je to neločljivo povezano z zaupanjem. Zaupanje pomeni ponuditi možnost drugim, da se razvijejo, in skupaj dosegati nove, še neznane stvari.

Opisal bom primer vpeljave evritmije v delovni proces v Domu upokojencev Center, enota Poljane. V projektu je bila sprva predvidena udeležba med osem in deset zaposlenih na različnih delovnih mestih od strežnic, bolničark, negovalk do medicinskih sester, med projektom pa se je skupina povečevala. Učinki so presegli moja pričakovanja. Udeleženke so na veliko presenečenje ob koncu izpolnile neobvezno anketno polo, ki je od njih zahtevala opisne odgovore. Učinki na posameznike so bili glede na odgovore v anketi takojšnji, učinki na celoto pa bodo vidni kasneje. Udeleženke so povedale, da zdaj drugače vstopajo $\mathrm{v}$ odnose druga $\mathrm{z}$ drugo, da jim je laže sodelovati z vsemi, še posebej pa s tistimi sodelavkami, ki so se tudi udeležile izobraževanja. 


\section{IZHODIŠČE}

Izhodišče projekta je bilo, da zaposleni v delovnem vsakdanu deluje na različnih ravneh. Nekatere stvari mora opraviti sam, druge $\mathrm{v}$ paru s sodelavcem, tretje $\mathrm{v}$ skupini po tri ali več. Vsaka od teh ravni ima svoje posebnosti, ki se v delovnem vsakdanu odvijajo mimo zavesti udeleženih, rutinsko, velikokrat celo neproduktivno. Želeli smo, da udeleženci spoznajo te ravni in njihove posebnosti ter svoj način dela na vsaki izmed njih in da doživeto spoznajo svojo vlogo $\mathrm{v}$ skupini in pridobijo ali obnovijo zaupanje vase ter se na nov način lotijo običajnih nalog.

\section{METODA DELA}

Usposabljanja smo se lotili v štirih korakih, ki jih opisuje Scharmer (2011).

Prvi korak zajema spoznanje forme, po kateri se gibljemo oziroma predajamo in prejemamo lesene kroglice. V običajnem življenju je to formulirana naloga, ki jo moramo izpolniti.

Drugi korak se imenuje gibanje, $v$ jeziku gospodarstva mu rečemo timig. Nalogo moramo $\mathrm{Z}$ vmesnimi etapami opraviti $\mathrm{v}$ določenem času. Vstopiti moramo $\mathrm{v}$ element časa, ne da čas priganja nas, temveč da postanemo njegov gospodar in se gibljemo v njem. Ko gre za gibanje v skupini in križanje poti, moramo svojo pot $\mathrm{v}$ procesu do cilja variirati: v nekem trenutku korak umiriti, v drugem pospešiti. To zmoremo le, če je prvi korak - obvladanje forme - dovolj jasen.

Tretji korak se imenuje odnosi. Poleg prvih dveh elementov, forme in časa, začnemo zaznavati tudi svoje sodelavce. Najprej tiste, ki so v naši neposredni bližini, nato še preostale, ki sestavljajo tim. Ta korak privede do močne medsebojne povezave.

Šele ko je vzpostavljena ta raven delovanja, lahko preidemo na naslednji korak, imenovan intenca. Ko je skupina res močno povezana in deluje harmonično, se lahko v njej pojavi intenca, ki vse skupaj popelje k nečemu novemu. Iz skupne intence se rodi inovacija, novost. Intenca v skupini je nekaj, kar se lahko pojavi sinhrono pri več ljudeh hkrati, ki razmišljajo podobno. Drugi pa se temu priključijo, ker je »stvar « povsem življenjska in jo v trenutku lahko vzamejo za svojo.

Od tod naprej sledijo novi koraki, kajti nastalo novost je treba najprej pripraviti kot prototip in nato omogočiti, da se razširi.

\section{OBLIKA DELA}

Za dosego zastavljenih ciljev smo uporabili metodo evritmija za podjetja oziroma evritmija $\mathrm{v}$ delovnem procesu. $\mathrm{V}$ uvodu opisane tri ravni delovanja zaposlenega $\mathrm{v}$ evritmijskem procesu poimenujemo: prvo raven kot JAZ, drugo raven $\mathrm{v}$ paru kot TI in tretjo raven $\mathrm{v}$ skupini kot MI. Vsaka prinaša posamezniku drugačno izkušnjo. S pomočjo predajanja lesenih kroglic uresničimo te tri ravni in detajle, ki se v njih odvijajo, naredimo vidne za 
vse udeležence. S tem jim omogočimo poglobljeno razmišljanje o njihovem delovanju in odpremo pot za osebnostno rast.

\section{Raven 1: JAZ - kroglico predajam sebi}

Ko delujem sam, je pomembno zgolj to, da nalogo opravim v določenem času. Med samim delovanjem se mi ni treba nikomur prilagajati ne v načinu delovanja ne pri vmesnih časih. Če kakšno stvar naredim narobe, napako v času do dokončanja naloge laže odpravim in napaka tako sploh ne pride do izraza. Lahko se svobodno organiziram, vsa koncentracija je usmerjena na mene samega in ni nujno, da imam še kakšen interes za druge. Lahko se popolnoma skoncentriram na svojo nalogo in jo opravim.

\section{Raven 2: TI - kroglico moram predati drugemu in jo od drugega tudi sprejeti}

Povsem druga izkušnja nastane, ko moram svojo nalogo opraviti z nekom v paru. Pri vaji se takrat pojavijo prvi zahtevnejši izzivi, saj je treba nekoga poiskati ter z njim vzpostaviti stik in odnos. Tu se polje moje pozornosti od popolne koncentracije na samega sebe pomakne k nekomu drugemu. Začne se razvijati odnos med dvema, v katerega vsakdo prispeva del sebe. $\mathrm{V}$ ta odnos lahko vstopim povsem svobodno. To pomeni, da je zgolj od mene odvisno, kako se vedem do nekoga drugega. Vedenje je velikokrat vezano na neki formalno-neformalni kodeks, vendar pa vsak posameznik svobodno uresničuje ta kodeks v svoji notranjosti, kar navzven ni nujno takoj opazno. Pri vajah postavimo v ospredje prav ta moment. Gre namreč za predajo in sprejem kroglice. Kroglico lahko predam povsem zavestno in s polno odgovornostjo do prejemnika. V trenutku predaje me zanima le, kako je nekdo pripravljen to sprejeti. Največje veselje se porodi, ko ugotovim, da imam tudi sam vpliv na to, kako nekdo sprejema. Če je njegova dlan obrnjena navzdol, mu žogice ne morem predati na najboljši možni način, v tem primeru jo mora partner celo sam vzeti in sploh ne sprejeti. Imam pa možnost, da najdem način, kako zbuditi sodelavca, ne da bi mu karkoli rekel. Zadeva je v vaji povsem očitna, nedvoumna in enostavna, kar za delovno okolje težko rečemo, če ni zavesti in pregleda nad tem, kaj je treba storiti. Vaja najprej spodbudi razmišljanje o lastnem delovanju na delovnem mestu, nato pa začne delovati domišljija, kako bi lahko na nekonflikten način prebudili sodelavca, ki svojega dela ne vidi v celoti. Delovanje na ravni TI mi že pokaže, koliko sem se pripravljen in v danem trenutku tudi sposoben prilagajati drugemu. Še bolj postane očiten pomen timiga. Vendar se hitro ugotovi, da se lahko dva odlično ujameta v napačnem delu in tega sploh ne vesta, kljub temu da je na koncu vse videti brezhibno. Samo pozoren opazovalec odkrije anomalije $\mathrm{v}$ procesu. Te so na nekaterih delovnih mestih usodne, drugod pa gredo neopaženo mimo. Ko pozornost usmerimo v proces, ugotovimo, da se nam v njegovem delovanju vedno odkriva kaj novega, ne samo anomalije, lahko se pred nami nenadoma pojavi inovacija. V tem primeru se zgodi, da gledamo iz sedanjosti v prihodnost. Gledamo nekaj, kar sploh še ne obstaja in ne bo ugledalo luči sveta, če v razvoj ne bo vložene dovolj energije. 


\section{Raven 3: MI - žogico je treba nekomu predati in jo $\mathrm{v}$ istem trenutku od drugega sprejeti}

Še zahtevnejša in vedno tudi najbolj zabavna situacija nastane, ko moramo sodelovati vsaj trije hkrati, saj moramo kroglice v skupini predati sočasno. Zato je treba pozornost še bolj natančno usmeriti k drugim. Medtem ko smo jo najprej usmerili zgolj nase in nato pri delu v paru na partnerja, hkrati pa smo nadzorovali dajanje in sprejemanje, se moramo zdaj skoncentrirati zgolj na soseda, ki mu predajamo. Nastane nova izkušnja, saj se moram še bolj odpreti svetu, kajti kroglica, ki jo predajam, gre na eno stran, dlan, ki sprejema, na drugo. Zaupanje v nas je tu močno nagovorjeno. Izkaže se za nujen gradnik skupnega delovanja, ki ni nič manj pomemben od odgovornosti. Kako in koliko zaupam, mi postane jasno na tej ravni. O sebi hitro ugotovim, kakšen sem v danem trenutku in kaj to pomeni za delovanje skupine kot celote. Rešitev je spet povsem enostavna, ko o njej premišljujem, saj se moram le osredotočiti na to, v katero smer gre moja odgovornost, in da moram na drugo stran izkazati dovolj zaupanja. V praksi pa je vse skupaj precej težje, čeprav je treba v vaji zgolj v eno stran predati kroglico in jo na drugi sprejeti. Tu je možnosti za anomalije v procesu mnogo več in so tudi usodnejše. Vendar je zanimivo, da se pri vaji ob anomaliji oziroma napaki sprva vedno pojavi smeh. Ko se stvar zaplete, nihče več ne ve, kdo se je prvi zmotil. Vsi se prej ali slej začnejo smejati. Vzdušje se sprosti (zanimivo je, da se je to zgodilo tako pri skupini odraslih kot tudi pri dijakih, starih 16 let). Situacija postane kaotična, a ta kaos je zdrav, saj ugotovimo, da ne vemo, kaj se je v realnosti sploh zgodilo. V nasprotju z običajnim življenjem nam vaja to takoj in brezobzirno pokaže. Ko ta kaos doživimo, v njem nočemo vztrajati in delati na silo. Hitro spet uredimo vrste in se ne sprašujemo, kdo je kaj narobe naredil, ampak ali je vsakemu od nas povsem jasno, kaj naloga zahteva od nas. Večinoma je udeležencem to zelo razumljivo. Ugotovimo pa, da je za delovanje $\mathrm{v}$ življenju oziroma podjetju izjemno pomembno, da stvari preidejo »iz glave v roke« in v svet. Namesto iskanja krivcev za nastalo situacijo se hitro dogovorimo, da se bo vsak držal zgolj tistega, kar naloga zahteva od njega, in poskusimo še enkrat.

$\mathrm{V}$ drugem poskusu vaja $\mathrm{v}$ začetku dobro steče in se zaplete šele po nekaj korakih. Namesto krohotanja se zdaj hitreje pojavi želja, da poskusimo še enkrat. Največji uspeh pa je $\mathrm{v}$ tem, da udeleženci doživijo, kako razpravljanje o napaki ne vodi nujno k njeni odpravi, zagotovo pa vzame veliko časa in energije. Edino, kar anomalijo lahko odpravi, je prisotnost in prisebnost vsakega posameznika, njegova lastna motivacija, da bo v procesu osredotočen na nalogo, na čas in na sodelavca. Zato si v glavi ponovimo pravila in poskušamo vizualizirati lastno pot. Obenem se dogovorimo, da vajo izpeljemo »analitično«, $\mathrm{s}$ postanki ob vsaki predaji, po vsakem vmesnem cilju, da lahko premislimo, kam moramo naprej. Izkaže se, da smo v sodobnosti večinoma vzgojeni v analitični način razmišljanja. ${ }^{1}$ Reševanje težav in zapletov med delovanjem nam je bolj kot ne tuje. A po enem analitičnem poskusu razvijemo zamisli, kako se lahko stvari rešujejo med delovanjem, in

1 Analitično razmišljanje je kot dejavnost, ki poteka od točke do točke in se pri vsaki ustavi, da analizira minulo dejanje. Je dejavnost, ki je drugačna od življenja ali delovnega procesa, ki poteka zvezno in zato potrebuje tudi temu primerno orodje: gibljivo mišljenje. 
ko se prihodnjič zaplete, ne obstanemo in stvar rešujemo v teku delovanja. $\mathrm{V}$ tem trenutku se začenja rojevati in razvijati »procesna kompetenca ${ }^{2}{ }^{2}$

Ni enostavno, vendar vaje pokažejo, da je mogoče, če sem se pripravljen z napako soočiti in boriti ter če imam za to podporo sodelavcev, ki namesto da bi obtoževali in se posmehovali, s svojo pozornostjo in pregledom nad situacijo proces peljejo dalje in se ne ustavijo. Obtoževanje in posmeh kakor tudi tarnanje in vznemirjanje nujno zahtevajo ustavitev delovanja in vrtanje v preteklost, ne da bi šli prihodnosti naproti. To je tudi eno izmed doživetij na tej ravni.

\section{Evalvacija je pokazala}

Medtem ko so udeleženci prvi dan še z začudenjem ali dvomom opazovali, kaj se dogaja, so po drugem srečanju odhajali z nasmehom. Tretji dan se je že pojavilo vprašanje: »V̌̌eraj sem potem razmišljala, kaj novega se bo še zgodilo.«Vsak dan se je zgodilo kaj novega, tudi če smo samo ponovili stare vzorce. Ugotovili so namreč, da že zgolj z usmerjanjem pozornosti na različne detajle ista pot postane nova. Ko pa gre za sodelovanje, je vsaka situacija nova, če se je ne lotim na vseh ravneh rutinsko. Nekatere stvari se morajo nujno izvajati rutinsko, naša pozornost pa je težko rutinska. Udeleženci so v pogovoru povedali, da zdaj ob vstopu v sobo »vidim več kot pred tem, vidim, kako je soba urejena, vidim, kaj še lahko premaknem, in to mi ne pomeni teže, temveč zadovoljstvo. « Druga udeleženka je poročala, da ugotavlja, kje se preveč žene in troši zadnje atome moči, in da zdaj išče način, kako naj stvar uredi. Povedali so tudi, da so postali bolj pozorni na lastne gibe, ki so na dolgi rok lahko usodni, saj dnevno prestavijo verjetno okoli 500 kilogramov, ne da bi se tega sploh zavedali.

Doživetja so bila različna, vendar je zanimivo, da so se v nekaterih stvareh strnila. Vsi udeleženci so povedali, da so se med seboj močneje povezali, da bi si želeli, da takšno izobraževanje doživijo vsi zaposleni. Zelo toplo pa so pozdravili tudi to, da je bilo usposabljanje med delovnikom in da so se za kratko odklopili od vsakodnevne rutine, obenem jih je gibanje prebudilo in omogočilo, da so potem laže nadaljevali svoje delo.

\section{SKLEP}

Evritmija za podjetja oziroma evritmija v delovnem procesu je nov način izobraževanja zaposlenih odraslih. Svoja izhodišča ima v pedagoški, umetniški in tudi zdravilni evritmiji (Steiner, 2011). Njen namen je prebuditi pozornost posameznika za različne detajle, ki se odvijajo med ljudmi. Vsak trud, ki ga vložimo v to, da bi videli, kaj se dogaja okoli nas, nam obenem že prebuja tudi »speče« sposobnosti spoprijemanja $s$ temi dogodki. Če se nečesa zavem in hočem o tem izvedeti čim več, se mi hkrati razvija sposobnost, da se s tem tudi spopadam. In evritmija s svojo univerzalnostjo omogoča

2 Procesno kompetenco pojmujemo kot sposobnost sledenja procesom, sprotnega prilagajanja in korigiranja procesov, ne da bi jih ustavljali in začenjali znova. S pomočjo evritmije za podjetja to sposobnost prihodnosti, ki jo sodobnost potrebuje že zdaj, budimo v življenje in jo pomagamo krepiti. 
prav to. Vsakemu daje možnost, da doživi sebe v interakciji z drugimi, vidi lahko, kako deluje v različnih situacijah, ko je treba skupaj z drugimi nekaj storiti. Doživetja med izvajanjem vaj udeležencu omogočijo nestresno srečanje s samim seboj. Če ugotovi, da ima na nekem področju primanjkljaj, v evritmijskem procesu lahko doživi, kako mu okolje pomaga, da to odpravi. Vzpostavi zaupanje, da v svetu, med ljudmi vedno lahko najde oporo, če se le sprosti, pogleda in si dovoli, da so prvi koraki pri učenju nove sposobnosti vedno negotovi. Velika moč evritmije je $\mathrm{v}$ tem, da $\mathrm{v}$ kratkem času in na konkreten, praktičen način pokaže, kaj je za sodelovanje pomembno, kako se »šola « pozornost in izoblikuje nova sposobnost sledenja procesom, posamezniku pa prepusti, da se popolnoma samostojno odloči, kako bo deloval.

Ker spoznanja o sodelovanju izpeljemo iz gibalnih vaj, med izobraževanjem ni nikoli dolgčas, gibanje samo pa pri udeležencih ustvari prijetno počutje in poveča koncentracijo za delovne naloge. Evritmija nam pokaže, da je za sodobno sodelovanje potreben »prebujen posameznik «, ki si hoče v skupnem delovanju najti lastne izzive. Če zaposleni poskuša delovati na takšen način, potem služba postane njegov poklic, motivacija za delo pa ni več vprašljiva.

\section{LITERATURA}

Brater, M., Büchele, U. in Herzer, H. (1987). Eurythmie am Arbeitsplatz. Stuttgart:

Verlag Freies Geistesleben.

Maier-Smits, L. (2011). Začetki evritmijske umetnosti. Človek in svet, 3(2/3), 3-8.

Scharmer, C. O. (2011). Theorie U. Heidelberg: Carl-Auer Verlag.

Steiner, R. (1990). Eurythmie als sichtbare Sprache. Dornach: Rudolf Steiner Verlag.

Steiner, R. (1999). Eurythmie - Die Offenbarung der sprechenden Seele. Dornach: Rudolf Steiner Verlag.

Steiner, R. (2001). Eurythmie als sichtbarer Gesang. Dornach: Rudolf Steiner Verlag.

Steiner, R. (2003). Heileurythmie. Dornach: Rudolf Steiner Verlag.

Steiner, R. (2011). Evritmijska umetnost, Človek in svet, 3(2/3), 9.

Stronks, L. (2013). V pogovoru z Annemarie Ehrlich. Pridobljeno s https://www.youtube.com/ watch? $=$ qaWdd7nOCqU; https://www.youtube.com/watch?v=TVrm4ntlfds. 